\title{
Serological and Biochemical Characterization of Dengue Viral Infection in Clinical Isolates, 2019 Study
}

Akshita Verma ${ }^{1},{ }^{2 *}$, Monika Basera ${ }^{1},{ }^{2}$, Sandhya Maurya ${ }^{3},{ }^{1}$, Pratiksha Thapa ${ }^{1}$, Sandeep Singh $^{1}$, Shilpa Semwal ${ }^{1}$, Komal Gupta $^{1}$, Vivek Kumar $^{1}$, Vijay Kumar ${ }^{1}$, Divy Prakash Pandey ${ }^{1}$, Narotam Sharma ${ }^{1}$

${ }^{1}$ DNA Labs-A Centre for Applied Sciences, Dehradun, Uttarakhand, Indi

${ }^{2}$ Uttaranchal College of Science and Technology, Dehradun, Uttarakhand, India

${ }^{3}$ Swami Rama Himalayan University, Dehradun, Uttarakhand, India

DOI: $10.36347 /$ sjams.2021.v09i01.021

| Received: 02.01.2021 | Accepted: 18.01.2021 | Published: 19.01.2021

*Corresponding author: Akshita Verma

Abstract

Original Research Article

Introduction: Dengue is a vector borne viral disease caused by dengue virus (DENV), transmitted to host with the help of vector (Aedes aegypti and Aedes albopictus). Materials and Methods: Serological and biochemical tests was done in laboratory for the determination of NS1 antigen, IgG and IgM antibody. Complete blood count was also done. Result: A total of 278 cases were carried, out of which 119 of dengue virus reactive cases were considered for the proposed study. Serological markers NS1 antigen, $\operatorname{IgM}$ and $\operatorname{IgG}$ were found reactive. Also dengue virus shows clinical relevance on platelets count and total leucocyte count. Conclusion: Dengue virus come as an epidemic every year. Due to dengue virus, platelets count and leucocyte count decreases drastically, also a bit affect on erythrocytes and hemoglobin.

Keywords: Dengue viral infection, Flaviviridae, Erythrocytes, Leucocytes, Non structural protein 1(NS1), Immunoglobulins (Ig), Platelets, Morbidity, Mortality, Infection, Hemoglobin, Viral disease.

Copyright $(\mathcal{C} 2021$ The Author(s): This is an open-access article distributed under the terms of the Creative Commons Attribution 4.0 International License (CC BY-NC 4.0) which permits unrestricted use, distribution, and reproduction in any medium for non-commercial use provided the original author and source are credited.

\section{INTRODUCTION}

Dengue virus is a seasonal disease and can causes morbidity and mortality [1]. Dengue is caused by dengue virus (DENV) which belongs to family of Flaviviridae in the genus Flavivirus. Dengue is transmitted to human by Aedes species mosquitoes (Aedes aegypti and Aedes albopictus mosquito bite during day light hour), which thrive in tropical and sub tropical urban centers around the globe [2]. There are some other important human pathogens like Japanese encephalitis virus (JEV), West Nile virus (WNV), Yellow fever virus(YFV) and the recently re-emerged Zika virus (ZIKV) are closely related to Flaviviruses. The DENV consists of a single stranded positive sense RNA (ssRNA) and also contain capsid that is surrounded by an envelope containing the protein $\mathrm{E}$ and E dimer. The three structure proteins (capsid, E and $\mathrm{prM} / \mathrm{M}$ ) plus seven non structural proteins are transcribed and translated during viral replication [3]. Flavivirus has four genetically related but antigenically distinct serotypes of the virus (DEN-1, DEN-2,DEN-3 and DEN-4). After infection with a specific serotype, a person is thought to acquire lifelong immunity to that serotype [4]. Dengue infection shows flu like symptoms like headache, retroorbital pain, joint pain, rash, myalgia, arthralgia and some cases are asymptomatic [5]. In 2019, in India dengue was the most rapidly spreading vector-borne viral disease, with an increasing of areas at risk and there are $\sim 67,377$ dengue cases till October, 2019 [6]. The clinical manifestation of dengue follow three phase that is an initial febrile phase, a critical phase and spontaneous recovery phase [7]. Thus in the current research work we studied the biochemical, microbiological and other parameters involved during dengue viral infection in this year 2019.

Materials and Methods: For the proposed study, samples were collected from different hospitals in and around Dehradun region and the analysis of the specimen were carried out at DNA Labs A Center for Applied Sciences (DLCAS), Dehradun, Uttarakhand. Serum was separated from whole blood by non cooling centrifugation for 5 minutes at $3000 \mathrm{rpm}$. The serological testing was done for the characterization of NS1 antigen, IgG and IgM antibodies of Dengue Virus and was done by using Biolines Sd Dengue Duo Dengue NS1 + Ab Combo (Cat. No.11FK 45,11FK46) kit based method, which is a Immunochromatographic 
assay [8]. We have also performed the comparative study of Complete Blood Count (CBC) parameter Hemoglobin (Hb), Total leucocyte count (TLC), Erythrocytes count, Platelets count were detected by using semi automated $\mathrm{CBC}$ analyser (Mindray BC 2800).

\section{RESULTS}

Between September 2019 to October 2019 confirmed 119 positive cases for Dengue Viral infection were reported in this study. The data is arranged in tabular form as per Age group, $\mathrm{CBC}$ parameters and gender.

Table-1: Age Wise and Serological markers Distribution of Dengue Viral Infection

\begin{tabular}{|l|l|l|l|l|l|l|l|l|}
\hline \multirow{2}{*}{$\begin{array}{l}\text { Age group } \\
\text { in years) }\end{array}$} & \multirow{2}{*}{$\begin{array}{l}\text { No. of } \\
\text { cases }\end{array}$} & & Dengue virus serological analysis & $\begin{array}{l}\text { IgG+ } \\
\text { IgM } \\
\text { reactive }\end{array}$ & $\begin{array}{l}\text { NS1+IgG } \\
\text { reactive }\end{array}$ & $\begin{array}{l}\text { NS1+IgM } \\
\text { reactive }\end{array}$ & $\begin{array}{l}\text { NS1+IgG+IgM } \\
\text { reactive }\end{array}$ \\
\cline { 3 - 9 } & & Cases/\% & Cases/\% & Cases/\% & Cases/\% & Cases/\% & Cases/\% & Cases/\% \\
\hline $0-10$ & $6(5.04 \%)$ & $6(5.76 \%)$ & $1(3.03 \%)$ & $6(14.28 \%)$ & $0(0 \%)$ & $0(0 \%)$ & $5(4.20 \%)$ & $1(0.84 \%)$ \\
\hline $11-20$ & $25(21.0 \%)$ & $24(23.07 \%)$ & $5(15.15)$ & $14(33.33 \%)$ & $0(0 \%)$ & $0(0 \%)$ & $8(6.72 \%)$ & $4(3.36 \%)$ \\
\hline $21-30$ & $44(36.97 \%)$ & $37(35.57 \%)$ & $13(39.39)$ & $10(23.80 \%)$ & $1(0.84 \%)$ & $3(2.52 \%)$ & $3(2.52 \%)$ & $5(4.20 \%)$ \\
\hline $31-40$ & $19(15.96 \%)$ & $16(15.38 \%)$ & $8(24.24)$ & $3(7.14 \%)$ & $2(1.68 \%)$ & $5(4.20 \%)$ & $1(0.84 \%)$ & $0(0 \%)$ \\
\hline $41-50$ & $13(10.92 \%)$ & $12(11.53 \%)$ & $3(9.09)$ & $3(7.14 \%)$ & $1(0.84 \%)$ & $1(0.84 \%)$ & $2(1.68 \%)$ & $1(0.84 \%)$ \\
\hline $51-60$ & $10(8.04 \%)$ & $7(6.73 \%)$ & $3(9.09)$ & $4(9.52 \%)$ & $0(0 \%)$ & $0(0 \%)$ & $3(2.52 \%)$ & $0(0 \%)$ \\
\hline Above 60 & $2(1.68 \%)$ & $2(1.92 \%)$ & $0(0 \%)$ & $2(4.76 \%)$ & $0(0 \%)$ & $0(0 \%)$ & $2(1.68 \%)$ & $0(0 \%)$ \\
\hline $\begin{array}{l}\text { Total no. of } \\
\text { cases }\end{array}$ & 119 & $104(87.39 \%)$ & $33(27.73 \%)$ & $42(35.29 \%)$ & $4(3.36 \%)$ & $9(7.56 \%)$ & $24(20.16 \%)$ & $11(9.24 \%)$ \\
\hline
\end{tabular}

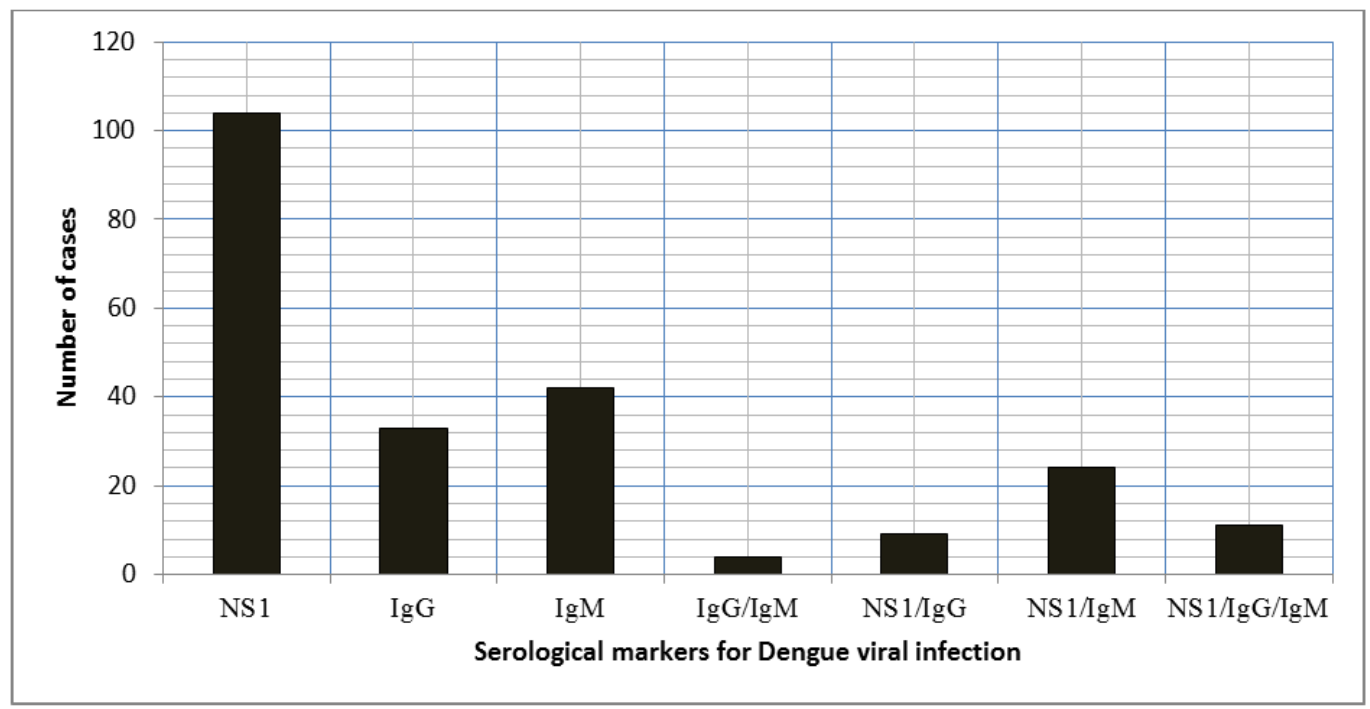

Fig-1: Bar graph of serological distribution of dengue viral infection

Table-2: Seasonality Variation of Dengue Viral Infection in Dehradun Population in 2019

\begin{tabular}{|l|l|l|}
\hline S. No & Month & No. of cases \\
\hline 1. & January & - \\
\hline 2. & February & - \\
\hline 3. & March & - \\
\hline 4. & April & - \\
\hline 5. & May & - \\
\hline 6. & June & - \\
\hline 7. & July & - \\
\hline 8. & August & - \\
\hline 9. & September & $86(72.2 \%)$ \\
\hline 10. & October & $33(27.73 \%)$ \\
\hline 11. & November & - \\
\hline 12. & December & - \\
\hline Total & & 119 \\
\hline
\end{tabular}


Akshita Verma et al; Sch J App Med Sci, Jan, 2021; 9(1): 105-108

Table-3: Complete Blood Count Profiling of Dengue Viral Infection Cases, in 2019

\begin{tabular}{|c|c|c|c|c|c|c|c|}
\hline \multicolumn{2}{|c|}{$\begin{array}{l}\text { Hemoglobin } \\
\text { (Normal Range:12-15 g/dl) }\end{array}$} & \multicolumn{2}{|c|}{$\begin{array}{l}\text { Erythrocytes } \\
\text { (Normal Range:3.80-4.80 } \\
\text { million/mm3) }\end{array}$} & \multicolumn{2}{|c|}{$\begin{array}{l}\text { Leucocyte Count } \\
\text { (Normal Range:4000-11000 } \\
\text { Cells/mm3) }\end{array}$} & \multicolumn{2}{|c|}{$\begin{array}{l}\text { Platelets Count } \\
\text { (Normal Range:1.50-4.0 } \\
\text { Lakh/mm3) }\end{array}$} \\
\hline Range & No. of cases $(\%)$ & Range & No. of cases $(\%)$ & Range & No. of cases $(\%)$ & Range & No. of cases $(\%)$ \\
\hline $9.0-10$ & $4(3.36 \%)$ & $3.0-3.50$ & $6(5.04 \%)$ & $1000-2000$ & $4(3.36 \%)$ & Below 0.50 & $1(0.84 \%)$ \\
\hline $10.01-11$ & $10(8.04 \%)$ & $3.51-4.00$ & $15(12.60 \%)$ & $2100-3000$ & $28(23.52 \%)$ & $0.50-1.00$ & $40(33.61 \%)$ \\
\hline $11.01-12$ & $12(10.08 \%)$ & $4.01-4.50$ & $31(26.0 \%)$ & $3100-4000$ & $43(36.1 \%)$ & $1.01-1.50$ & $48(40.33 \%)$ \\
\hline $12.01-13$ & $28(23.52 \%)$ & $4.51-5.00$ & $31(26.0 \%)$ & $4100-5000$ & $22(18.48 \%)$ & $1.51-2.00$ & $17(14.28 \%)$ \\
\hline $13.01-14$ & $26(21.84 \%)$ & $5.01-5.50$ & $26(21.84 \%)$ & $5100-6000$ & $7(5.88 \%)$ & $2.01-2.50$ & $6(5.04 \%)$ \\
\hline $14.01-15$ & $29(24.36 \%)$ & $5.51-6.00$ & $9(7.56 \%)$ & $6100-7000$ & $6(5.04 \%)$ & $2.51-3.00$ & $7(5.88 \%)$ \\
\hline $15.01-16$ & $6(5.04 \%)$ & $6.01-6.50$ & $1(0.84 \%)$ & $7100-8000$ & $5(4.20 \%)$ & & \\
\hline $16.01-17$ & $4(3.36 \%)$ & & & $8100-9000$ & $4(3.36 \%)$ & & \\
\hline
\end{tabular}

Table-4: Gender Wise distribution of Hemoglobin and Platelets count Profiling of Dengue Virus Infection Cases

\begin{tabular}{|c|c|c|c|}
\hline \multicolumn{2}{|l|}{ Hemoglobin } & \multicolumn{2}{|l|}{ Platelets } \\
\hline Range & Cases as per gender & Range & Cases as per gender \\
\hline $1-10.0$ & $\begin{array}{l}\text { Male- } 1(0.83 \%) \\
\text { Female-3(2.52\%) }\end{array}$ & Below 0.50 & $\begin{array}{l}\text { Male- } 1(0.83 \%) \\
\text { Female- } 0(0 \%)\end{array}$ \\
\hline $10.01-11.0$ & $\begin{array}{l}\text { Male-1 }(0.83 \%) \\
\text { Female- } 9(7.56 \%)\end{array}$ & $50.0-1.00$ & $\begin{array}{l}\text { Male- } 23(19.32 \%) \\
\text { Female- } 17(14.28 \%)\end{array}$ \\
\hline-12.0 & $\begin{array}{l}\text { Male-2 }(1.68 \%) \\
\text { Female-10(8.40\%) }\end{array}$ & $1.01-1.50$ & $\begin{array}{l}\text { Male- } 33(27.73 \%) \\
\text { Female- } 15(12.60 \%)\end{array}$ \\
\hline $12.01-13.0$ & $\begin{array}{l}\text { Male-11(9.24\%) } \\
\text { Female-17(14.28\%) }\end{array}$ & $1.51-2.0$ & $\begin{array}{l}\text { Male- } 7(5.88 \%) \\
\text { Female- } 10(8.40 \%)\end{array}$ \\
\hline $13.01-14.0$ & $\begin{array}{l}\text { Male-18(15.12\%) } \\
\text { Female-8(6.72\%) }\end{array}$ & $2.01-2.50$ & $\begin{array}{l}\text { Male- } 2(1.68 \%) \\
\text { Female- } 4(3.36 \%)\end{array}$ \\
\hline $14.01-15.0$ & $\begin{array}{l}\text { Male-27(22.68\%) } \\
\text { Female-2(1.68\%) }\end{array}$ & $2.51-3.0$ & $\begin{array}{l}\text { Male- } 3(2.52 \%) \\
\text { Female- } 4(3.36 \%)\end{array}$ \\
\hline $15.01-16.0$ & $\begin{array}{l}\text { Male-0(0\%) } \\
\text { Female-695.04\%) }\end{array}$ & & \\
\hline $16.01-17$ & $\begin{array}{l}\text { Male-3(2.52\%) } \\
\text { Female-1(0.83\%) }\end{array}$ & & \\
\hline
\end{tabular}

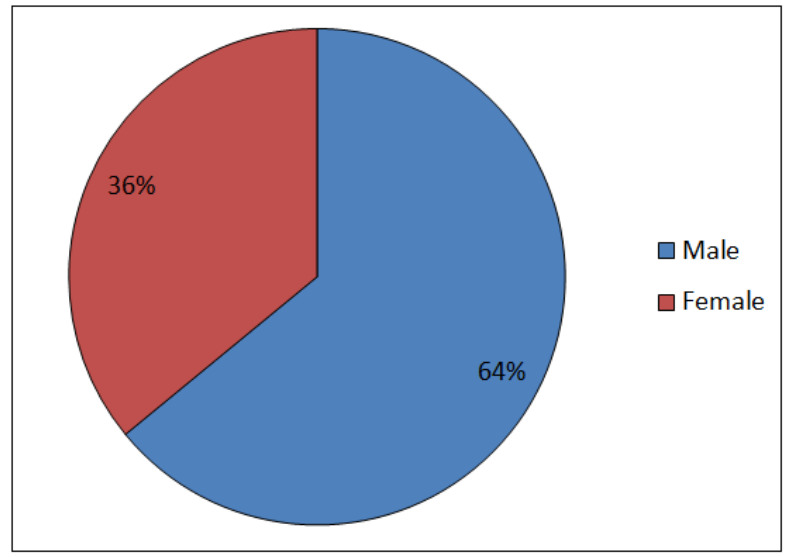

Fig-2: Pie chart of male and female below noraml range of platelets

In the study, total number of 278 cases with symptoms like fever, joint pain, retro orbital pain, shivering, fatigue, frontal headache were considered from august 2019 to October 2019, 119 came reactive for dengue viral infection out of which 104(87.39\%) cases were positive for NS1, followed by $\mathrm{IgG}$ contributing $33(27.73 \%)$ and $42(35.29 \%$ ) reactive for IgM. Out of 119 confirmed positive cases, 4(3.36\%) were reactive for both $\operatorname{IgG}+\operatorname{IgM}, 9(7.56 \%)$ for
$\mathrm{NS} 1+\mathrm{IgG}, 24(20.16 \%)$ for $\mathrm{NS} 1+\mathrm{IgM}$ and $11(9.24 \%)$ cases reactive for $\mathrm{NS} 1+\mathrm{IgG}+\mathrm{IgM}$. It was found that the most prominent age group for dengue viral infection was between 21 to 30 years with $44(36.97 \%)$ cases followed by 11 to 20 years with $25(21.0 \%$ ) cases out of 119 confirmed cases. The most of the cases between age group 21 to 30 was NS1 reactive contributing 37 $(35.57 \%)$ and between age group 11 to 20 which was second most prominent age group for NS1 reactive cases with 24 (23.07\%). The most prominent age group for IgG reactive cases was also between 21-30 years $(39.39 \%)$ and for $\operatorname{IgM}$ is $11-20$ years $(33.33 \%)$ (As shown in Table-1 and Fig-1). Study was also done with respect to seasonality variations, month wise; It was seen that in September, 2019 the cases was maximum, (72.2\%) followed by October $(27.73 \%)$ (Table-2). CBC profiling was done for all the 119 cases. It was analysed that hemoglobin was found to be as normal parameters in $83(69.74 \%$ ) cases. In $10(8.40 \%)$ cases hemoglobin was above the normal range. Also 26(21.84\%) cases were with low hemoglobin. It was seen that in $75(65 \%)$ cases, leucocyte count found to be as below normal range (As depicted in Table-3). Gender wise CBC profiling was also done for all 119 cases. It was analysed that platelets count found to be below normal 
ranges in $89(74.78 \%$ ) cases in which $57(64$.) cases were male and $32(36 \%)$ were female (Table-4).

\section{Discussion AND CONCLUSION}

The epidemic of dengue viral infection can be measured by the morbidity and mortality rate of dengue [9]. According to our study, it was seen that most of the cases were found to be NS1 reactive followed by IgM as a serological markers. The existence of NS1 antigen shows actue phase infection, and it is typically detectable within 1-2 day [10]. NS1 test detect the nonstructural NS1 of dengue [8]. At initial stage of dengue infection, IgM antibody appears first which displays the current infection [11]. IgG antibody rises rapidly (shows the past infection) and high in acute phase before or with IgM after 10-14 days onset of symptoms [12]. The same pattern was seen in this study too. Dengue viral infection is seen post rainy season in Indian (sub continent).In the present study we only analysed on 278 cases, and it was seen that before September and October 2019, none was found reactive. Thus for dengue viral infection (vectors- Aedes Aegypti and Aedes Albopictus) rainfall, temperature, hygiene conditions and relative humidity plays a vital role [13]. Also the study was confined to in and around Dehradun region, thus can be done in different parts of Uttarakhand. The platelets count during dengue viral infection decreases due to early destruction of platelets or less production of platelets from bone marrow [14]. There are various other method to detect DENV i.e virus isolation, dengue specific IgM by MAC ELISA, detection of viral nucleic acid by RT-PCR [15].

\section{REFERENCES}

1. Mutsuddy $\mathrm{P}$, Tahmina Jhora S, Shamsuzzaman AK, Kaisar SM, Khan MN. Dengue situation in Bangladesh: An epidemiological shift in terms of morbidity and mortality. Canadian Journal of Infectious Diseases and Medical Microbiology. 2019 Jan 1;2019.

2. Messina JP, Brady OJ, Golding N, Kraemer MU, Wint GW, Ray SE, Pigott DM, Shearer FM, Johnson K, Earl L, Marczak LB. The current and future global distribution and population at risk of dengue. Nature microbiology. 2019 Sep;4(9):1508-15

3. John AL, Rathore AP. Adaptive immune responses to primary and secondary dengue virus infections. Nature Reviews Immunology. 2019 Apr;19(4):218-30.

4. Rocklöv J, Tozan Y. Climate change and the rising infectiousness of dengue. Emerging Topics in Life Sciences. 2019 May 10;3(2):133-42
5. Vaughn DW, Green S, Kalayanarooj S, Innis BL, Nimmannitya S, Suntayakorn S, Rothman AL, Ennis FA, Nisalak A. Dengue in the early febrile phase: viremia and antibody responses. Journal of Infectious Diseases. 1997 Aug 1;176(2):322-30.

6. Wilder-Smith A, Rupali P. Estimating the dengue burden in India. The Lancet Global Health. 2019 Aug 1;7(8):e988-9.

7. Simmons CP, Farrar JJ, van Vinh Chau N, Wills B. Dengue. New England Journal of Medicine. 2012 Apr 12;366(15):1423-32.

8. Sánchez-Vargas LA, Sánchez-Marce EE, Vivanco-Cid H. Evaluation of the SD BIOLINE dengue duo rapid test in the course of acute and convalescent dengue infections in a Mexican endemic region. Diagnostic microbiology and infectious disease. 2014 Apr 1;78(4):368-72.

9. Libraty DH, Young PR, Pickering D, Endy TP, Kalayanarooj S, Green S, Vaughn DW, Nisalak A, Ennis FA, Rothman AL. High circulating levels of the dengue virus nonstructural protein NS1 early in dengue illness correlate with the development of dengue hemorrhagic fever. The Journal of infectious diseases. 2002 Oct 15;186(8):1165-8.

10. Dussart P, Petit L, Labeau B, Bremand L, Leduc A, Moua D, Matheus S, Baril L. Evaluation of two new commercial tests for the diagnosis of acute dengue virus infection using NS1 antigen detection in human serum. PLoS Negl Trop Dis. 2008 Aug 20;2(8):e280.

11. Shrivastava A, Dash PK, Tripathi NK, Sahni AK, Gopalan N, Rao PL. Evaluation of a commercial dengue NS1 enzyme-linked immunosorbent assay for early diagnosis of dengue infection. Indian journal of medical microbiology. 2011 Jan $1 ; 29(1): 51$.

12. Groen J, Koraka P, Velzing J, Copra C, Osterhaus AD. Evaluation of six immunoassays for detection of dengue virus-specific immunoglobulin $\mathrm{M}$ and $\mathrm{G}$ antibodies. Clinical and diagnostic laboratory immunology. 2000 Nov 1;7(6):867-71.

13. Kamgang B, Happi JY, Boisier P, Njiokou F, HERVÉ JP, Simard F, Paupy C. Geographic and ecological distribution of the dengue and chikungunya virus vectors Aedes aegypti and Aedes albopictus in three major Cameroonian towns. Medical and veterinary entomology. 2010 Jun;24(2):132-41.

14. Assinger A. Platelets and infection-an emerging role of platelets in viral infection. Frontiers in immunology. 2014 Dec 18;5:649.

15. Rathakrishnan A, Sekaran SD. New development in the diagnosis of dengue infections. Expert Opinion on Medical Diagnostics. 2013 Jan 1;7(1):99-112. 